University of Nebraska - Lincoln

DigitalCommons@University of Nebraska - Lincoln

Karl Reinhard Papers/Publications

Natural Resources, School of

2015

Curatorial implications of Ophyra capensis (Order Diptera, Family Muscidae) puparia recovered from the body of the Blessed Antonio Patrizi, Monticiano, Italy (Middle Ages)

Johnica J. Morrow

University of Nebraska-Lincoln, Johnica.Morrow@sdsmt.edu

Diesel A. Baldwin

University of Nebraska-Lincoln

Leon G. Higley

University of Nebraska - Lincoln, lhigley1@unl.edu

Dario Piombino-Mascali

Vilnius University

Karl J. Reinhard

University of Nebraska-Lincoln, kreinhard1@mac.com

Follow this and additional works at: http://digitalcommons.unl.edu/natresreinhard

Part of the Archaeological Anthropology Commons, Ecology and Evolutionary Biology Commons, Environmental Public Health Commons, Other Public Health Commons, and the Parasitology Commons

Morrow, Johnica J.; Baldwin, Diesel A.; Higley, Leon G.; Piombino-Mascali, Dario; and Reinhard, Karl J., "Curatorial implications of Ophyra capensis (Order Diptera, Family Muscidae) puparia recovered from the body of the Blessed Antonio Patrizi, Monticiano, Italy (Middle Ages)" (2015). Karl Reinhard Papers/Publications. 74.

http://digitalcommons.unl.edu/natresreinhard/74

This Article is brought to you for free and open access by the Natural Resources, School of at DigitalCommons@University of Nebraska - Lincoln. It has been accepted for inclusion in Karl Reinhard Papers/Publications by an authorized administrator of DigitalCommons@University of Nebraska Lincoln. 


\title{
Curatorial implications of Ophyra capensis (Order Diptera, Family Muscidae) puparia recovered from the body of the Blessed Antonio Patrizi, Monticiano, Italy (Middle Ages)
}

\author{
Johnica J. Morrow, ${ }^{1}$ Diesel A. Baldwin, ${ }^{2}$ Leon Higley, ${ }^{1}$ \\ Dario Piombino-Mascali, ${ }^{3}$ and Karl J. Reinhard ${ }^{1}$
}

1 School of Natural Resources, University of Nebraska-Lincoln, 3310 Holdrege Street, Lincoln, NE, 68583-0987, USA

2 Department of Anthropology, University of Nebraska-Lincoln, 816 Oldfather Hall, Lincoln, NE, 68588-0368, USA

3 Faculty of Medicine, Vilnius University, MK Čiurlionis Street 21, LT-03101, Vilnius, Lithuania

Corresponding author - J.J. Morrow, 243c Hardin Hall-Section 6, 3310 Holdrege Street, Lincoln, NE, 68583-0962, USA;

email johnica@huskers.unl.edu

\begin{abstract}
The discovery of dipteran remains on mummified individuals can lead to either cause for curatorial concern or to a better understanding of the individual's post-mortem environment. The present study analyzed insect remains associated with the body of a unique medieval mummy of religious significance, that of the Blessed Antonio Patrizi da Monticiano. A total of 79 puparia were examined and all were identified as Ophyra capensis (Diptera: Muscidae). Additionally, a desiccated moth (Lepidoptera: Tineidae) was encountered. Puparia of $O$. capensis would be associated with normal decomposition shortly after the death of the mummified individual, and not an infestation beginning during more recent years. Similarly, the tineid moth found would likely be related with decomposition of cloth associated with the remains. These findings illustrate how collection and identification of insects associated with human remains can distinguish between historical decomposition versus issues of modern curatorial concern.
\end{abstract}

Keywords: Archaeoentomology, Forensic entomology, Taphonomy, Mummy, Curation, Puparia

\section{Introduction}

The process of decomposition is facilitated through a number of decomposer organisms, including fungi, bacteria, and insects. Many studies have been aimed at the succession of insects arriving during the various stages of decomposition. ${ }^{1-6}$ Beetles (Order Coleoptera), moths (Order Lepidoptera), and true flies (Order Diptera) have most often been the focus of these taphonomic studies.

Seven families within Order Diptera have significant roles in corpse and carcass decomposition. Early in decomposition, blowflies (Family Calliphoridae) are typically the first to arrive. Calliphorids can appear within minutes of death and often deposit eggs within the first daylight hours (they do not lay eggs at night). Members of the Family Muscidae (house/ stable flies) and the Family Sarcophagidae (flesh flies) also arrive during early decomposition. ${ }^{7}$ Subsequently, different types of insects arrive including members of the families Piophilidae (cheese skippers that are associated with bodies after adipocere formation), and Fannidae (little house flies that are often associated with fecal-contaminated tissues). ${ }^{1,5}$ As the fly larvae pierce through the corpse or carcass's skin, internal gases are released and deflation of the body occurs (when bloating is present). During this process, calliphorids most commonly remain the most abundant insects, but additional new flies belonging to the family Sepsidae (black scavenger flies) and other arthropods (e.g., beetle species) begin arriving. ${ }^{1,7}$

Once they complete their larval development, blow fly larvae migrate away from the body. As soft tissues disappear, new decomposers arrive. Generally, when remains are dry, the most likely insects associated with the body are beetles in the families Dermestidae and Cleridae. Even after burial, bodies may become infested with coffin flies (Family Phoridae). These minute flies can penetrate through dirt and find their way into sealed coffins and sarcophagi.

During the pupal stage of their life cycles, dipterans form puparia in which they undergo metamorphosis. Puparia, like many insect parts, are comprised of chitin, which preserves well for many years given the 
appropriate environmental conditions. The discovery of dipteran puparia within burial and mummy contexts can reveal a wealth of information to forensic entomologists. The first examination of flies from archaeological contexts was made by F.W. Hope following delivery of puparia collected during the unwrapping of the Leeds mummy. ${ }^{8}$ Identification of these puparia led Hope to the conclusion that the mummification process had taken an extended amount of time, allowing for the infestation of late-stage dipteran decomposers. Additional archaeological studies of insects from burials have helped researchers to reconstruct burial practices in prehistory. ${ }^{9,10}$ Teskey and Turnbull ${ }^{10}$ were able to assert that prehistoric Canadian burial practices included prolonged exposure to the environment prior to burial based on dipteran remains. In the present study, fly puparia were collected from a unique mummy of religious significance (Figs. 1 and 2). Samples were collected for identification of the puparia to determine the curatorial implications of their presence.

\section{Materials and methods}

We undertook the analysis of the puparia casings found in the Blessed Antonio Patrizi da Monticiano (Sienna), Italy, who is believed to have performed several miracles. ${ }^{11}$ Monticiano is located in Tuscany, where the mummified remains of a medieval subject were discovered and subsequently moved inside of the church of Saints Peter and Paul. Until recently, the mummy was displayed every ten years during catholic processions; he was otherwise stored in the church in a coffin constructed in 1699. In 1995 the mummy was transferred to a new coffin. Environmental conditions were probably altered, and humidity was likely amplified. Subsequently, mold was observed on the coffin and clothes. This suspected increase of humidity caused risk of biodeterioration to the Blessed Antonio Patrizi and the artifacts that surrounded him. The church officials requested an assessment of the preservation of the body.

Samples from the mummy (Fig. 1) were carefully collected in the fall of 2011 and submitted to the University of Nebraska-Lincoln. Utilizing an Olympus stereoscopic microscope, puparia were isolated from other debris, separated based on morphological differences, and counted. Broken puparia or puparia with obscure spiracles were not entered into the final count for this analysis. Samples were identified based on keys and references on relevant insect groups ${ }^{12-15}$ and compared with previously published work on Italian dipterans. ${ }^{16}$ Selected puparia were photographed

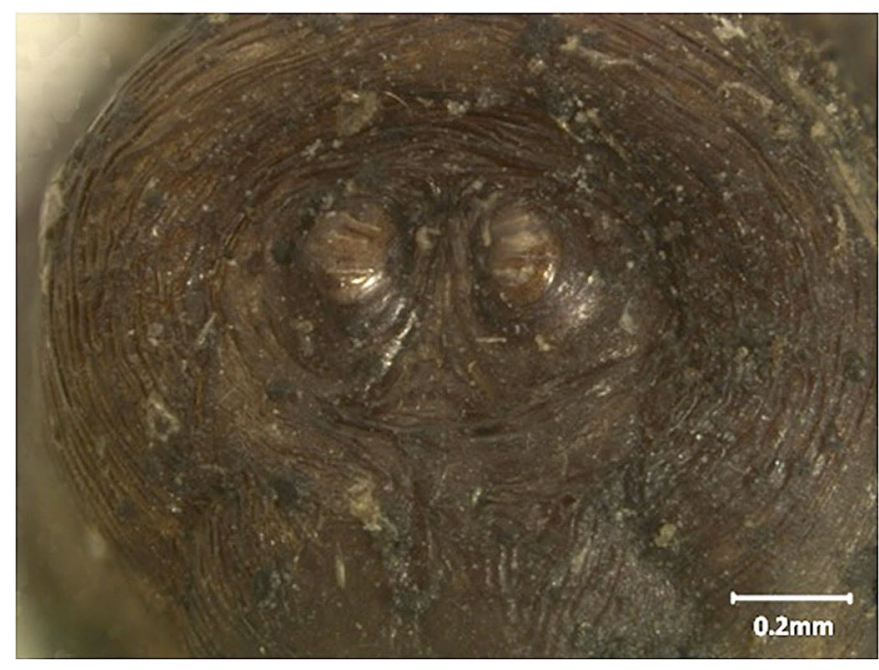

Fig. 2. Ophyra capensis puparium showing posterior spiracles. Image produced with a Leica (10447177) stereoscope with a PC-mount JVC digital camera (KY-F75U). The computer software Auto-Montage by Syncroscopy was used for the focused 3-D images.

with a PC-mount JVC digital camera (KY-F75U) under a Leica stereoscope (10447177). The computer software Auto-Montage by Syncroscopy was used to create the 3-D image (Fig. 2). The puparia were archived in an airtight glass vial and stored within the University of Nebraska-Lincoln's School of Natural Resources.

\section{Results and discussion}

At the time of corporeal inspection, we discovered a non-uniform distribution of puparia. The distribution was overwhelmingly gravity-dependent with the posterior surface of the body. Only a few puparia were scattered at other parts of the body. It could be that seepage of fluids to the posterior created an attractive environment for the flies. Eventually decomposition totally stopped when the body reached a critical level of desiccation.

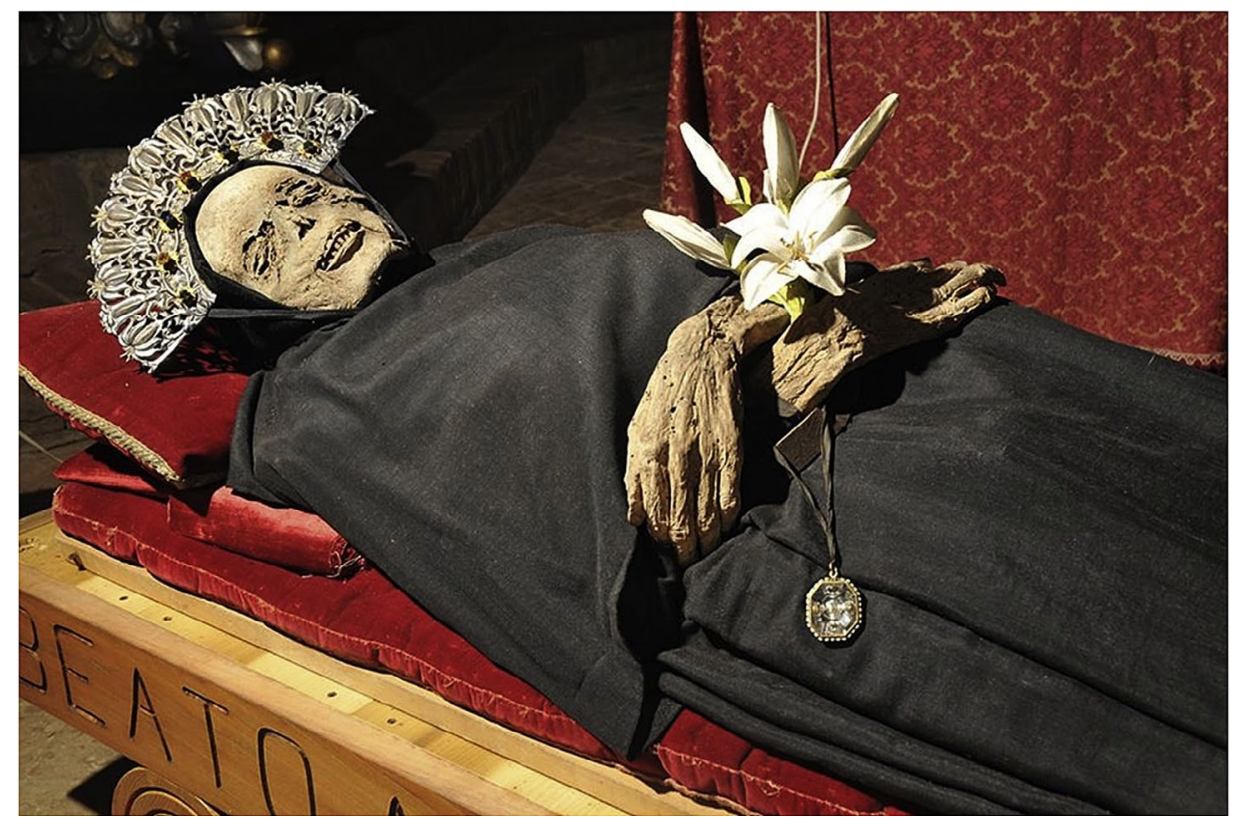

Fig. 1. The Blessed Antonio Patrizi da Monticiano. 
Table 1. Details on insect specimens recovered from remains of the Blessed Antonio Patrizi, and their identification based on morphological characteristics.

\begin{tabular}{llllll}
\hline Order & Family & Species & Number & Stage and state & ID References \\
\hline $\begin{array}{l}\text { Diptera } \\
\text { Lepidoptera }\end{array}$ & Muscidae & Ophyra capensis & 79 & Puparia: Most fragments, some whole & Smith. ${ }^{15}$ \\
& & $\begin{array}{l}\text { Likely Tinea pellionella } \\
\text { or Tineola bisselliella }\end{array}$ & 1 & Adult: Body very desiccated & Hinton $^{12}$; Carter. $^{19}$ \\
\hline
\end{tabular}

The numbers and identities of insect material recovered are shown in Table 1. Puparia of the muscid fly, Ophyra capensis, were abundant. Although puparia were mostly fragmentary, diagnostic structures associated with the posterior spiracles were sufficiently intact to allow species-level identification. An adult tineid moth was also recovered from the sample. This specimen was both desiccated and crushed, so species determination was not possible.

Insect remains can be important for understanding the taphonomic conditions associated with mummies. The presence of specific families of flies allows researchers a glimpse at the environmental conditions surrounding the body after death. The relative abundance of puparia from various dipteran families can give investigators insights into burial rituals, seasonality of death, and environmental conditions the body was exposed to post-mortem. ${ }^{9,10,17}$ Proper identification of puparia can also help mummy curators to assess whether or not a deterioration prevention plan is warranted.

The discovery of $O$. capensis puparia indicates that the body of the mummified individual is under no threat from current dipteran infestation. Ophyra species have been reported from other remains of historic interest, and their presence here would be associated with initial decomposition processes. The absence of insect remains from other families of dipterans suggests that the body was exposed to the natural environment for only a short time after his death. The lack of phorid remains suggests that the body was well-sealed. If this was not the case, these minute flies, notorious for their ability to enter coffins, would have been present. ${ }^{15,18}$

Tineid moths, such as the one recovered in the present study, are not directly associated with decomposition, but the larvae of some species do feed on cloth. The two tineid species most likely to be associated with feeding on cloth are Tinea pellionella or Tineola bisselliella. The recovery of an adult tineid with the remains is consistent with insect feeding on the clothing associated with the remains.

The presence of an adult tineid moth would be of curatorial concern if there were additional evidence of active degradation of material within the remains, or of an active moth infestation. Such evidence would certainly include either larval or pupal exuvia from tineids.

We observed small puncture damage to the mummy. Small circular or oval holes were scattered over the body but were especially obvious on hands and feet. Holes in the skin are commonly associated with movement and feeding by blow fly larvae after skin slippage, however, we do not expect to see a distribution of such holes over this mummified body. Consequently, we suspect that this damage was most likely caused by dermestid activity. Dermestid beetles are virtually ubiquitous agents of decomposition on dried flesh, hair, fur, and cloth. ${ }^{15}$ We did not observe active dermestids. Therefore we suspect that this possible dermestid activity occurred some time before present. Additionally, given that the remains had been moved at least three times, finding fragile puparia still in association with the body further speaks to the care with which the mummy must have been treated.

\section{Conclusions}

This investigation into insects associated with this mummy illustrates a largely unrecognized aspect of examining insects from archeological and historical remains. Such analysis may let curators distinguish between historical damage or decomposition, versus active threats.
Conflict of interest - None

Funding - None declared

Ethical approval — None declared

Acknowledgments - Auto-Montage images in this research were taken in the Biodiversity Synthesis Laboratory of the University of Nebraska State Museum (NSF/BS\&I Multi-user Equipment grant DBI 0500767 to M. L. Jameson and F. C. Ocampo). We are also indebted to Carlo Calossi, former Governor of the Company of the Blessed Antonio Patrizi, for advocating and supporting this project.

\section{References}

1. Payne JA. A summer carrion study of the baby pig Sus scrofa Linnaeus. Ecology 1965;46(5):511-23.

2. Rodriguez WC, Bass WM. Insect activity and its relationship to decay rates of human cadavers in East Tennessee. J For Sci 1983;28(2):423-32.

3. Schoenly K, Reid W. Dynamics of heterotrophic succession in carrion arthropod assemblages: discrete series or a continuum of change? Oecologia 1987;73(2): 192-202.

4. Campobasso CP, Di Vella G, Introna F. Factors affecting decomposition and Diptera colonization. For Sci Int 2001;120(1-2):18-27.

5. Grassberger M, Frank C. Initial study of arthropod succession on pig carrion in a central Europe urban habitat. J Med Ent 2004;41(3):511-23.

6. Kreitlow KLT. Insect succession in a natural environment. In: Byrd JH, Castner JL, editors. Forensic entomology: The utility of arthropods in legal investigations. CRC Press; 2010.

7. Anderson GS, Van Laerhoven SL. Initial studies on insect succession on carrion in southwestern British Columbia. J For Sci 1996;41(4):617-25.

8. Panagiotakopulu E. Dipterous remains and archaeological interpretation. J Arch Sci 2004;31:1675-84.

9. Gilbert MB, Bass WM. Seasonal dating of burials from the presence of fly pupae. Amer Ant 1967;32:534-5.

10. Teskey HH, Turnbull C. Diptera puparia from pre-historic graves. Can Entomol 1979;111:527e528.

11. Gagliardi I. Santi Frati e Corpi Santi: /l Beato Antonio (Patrizi) da Monticiano. Cantagalli: Siena. 2002.

12. Hinton HE. Larvae of the species of Tineidae of economic importance. Bull Entomol Res 1956;47:257-346.

13. McAlpine JF, Peterson BV, Shewell GE, Teskey HJ, Vockeroth JR, Wood DM, et al. Manual of Nearctic Diptera, vol. 1; 1981. Ottawa, Ontario.

14. McAlpine JF, Peterson BV, Shewell GE, Teskey HJ, Vockeroth JR, Wood DM, et al. Manual of Nearctic Diptera, vol. 2; 1987. Ottawa, Ontario.

15. Smith KGV. A manual of forensic entomology. Ithaca, New York: Cornell University Press; 1986.

16. Introna Jr JF, Campobasso CP, Di Fazio A. Three case studies in forensic entomology from southern Italy. J For Sci 1998;43:210-4.

17. Pettigrew TJ. A history of Egyptian mummies. London: Longman, Rees, Orme, Brown, Green \& Longman; 1834.

18. Palla F, Sineo L, Manachini B. Bacteria, fungi, and arthropod pests collected on modern human mummies. J Ent Acarol Res 2011;43(2):69-76.

19. Carter DJ. Pest Lepidoptera of Europe with special reference to the British Isles. In: Spencer KA, editor. Series entomologica, vol. 31. Dordrecht: Dr. W. Junk Publishers; 1984. 